by Cajus G. Diedrich

\title{
Huge accumulations of Upper Cretaceous giant ammonite shells in benthic islands of southern North Sea Basin of Central Europe
}

Paleologic, Nansenstr. 8, D-33790 Halle/Westph., Germany. Webpage: www.paleologic.de, E-mail: cdiedri@gmx.net

In the greenhouse world of the Early Upper Cretaceous of Europe giant cephalopod shells of the hemibenthic ammonite Puzosia formed huge accumulations. Their shells indicate adaptations in the body chamber morphology depending on the environment. On the sea floor, deposited ammonite shells scoured up to $50 \mathrm{~cm}$ depth which caught more and more large shells over extended periods of time. They built up to five square meter extended scour troughs in which the shells are enriched in chain-, fan- and fan layer orders with a maximum accumulation of 24 cephalopods. Between these hundreds of other macrofaunal remains accumulated. The ammonite shells were benthic islands and minibiotopes in carbonate soft- to firm ground environments along a submarine swell in the southern North Sea Basin of Central Europe. The empty shells encrusted by different epizoans sheltered and protected also crustaceans, which undermined the empty shells by bioturbation. Small and extremely rare squamate reptiles of the marine Dolichosaurus longicollis possibly took shelter or fed within these unique benthic submarine depression "islands".

\section{Introduction}

Ninety million years ago during the global greenhouse world within the Oceanic Anoxic Event II (Arthur et al., 1987; Gale, 1990; Schlanger et al., 1987; Diedrich, 2000b, 2001b) of the Uppermost Cenomanian (Upper Cretaceous), large empty ammonite shells scoured up to $50 \mathrm{~cm}$ into the underlying sediments, creating large depressions along a submarine swell in the southern boreal North Sea Basin (Diedrich, 2001a-d). Only in such traps the macrofauna is preserved in benthic hardground islands. On a surface of about $10 \mathrm{~m}^{2}$ a single giant ammonite scour trough was found; about 179 scour troughs on extremely large surfaces were studied between 19962001 (Diedrich, 2001b-c). On these surfaces, up to a maximum of 24 big ammonites accumulated, such as the unique find at the Borgholzhausen locality in north-west Germany (Fig. 1). Such giant accumulations started by a single ammonite shell, and continued with chain, fan, and fan layer ammonite orders, sometimes even in two overlapping layers (Diedrich, 2001b-c). The use of scour trough forms and the orientation of ammonites for palaeocurrent reconstructions are known (Brenner, 1976). Based on the enrichment order of the large ammonite shells in the Upper Cretaceous of North Sea Basin a northwesterly running main bottom current at the submarine swell region is inferred for the northwestern German sites. This points to periodical incursion of warm water masses from the east

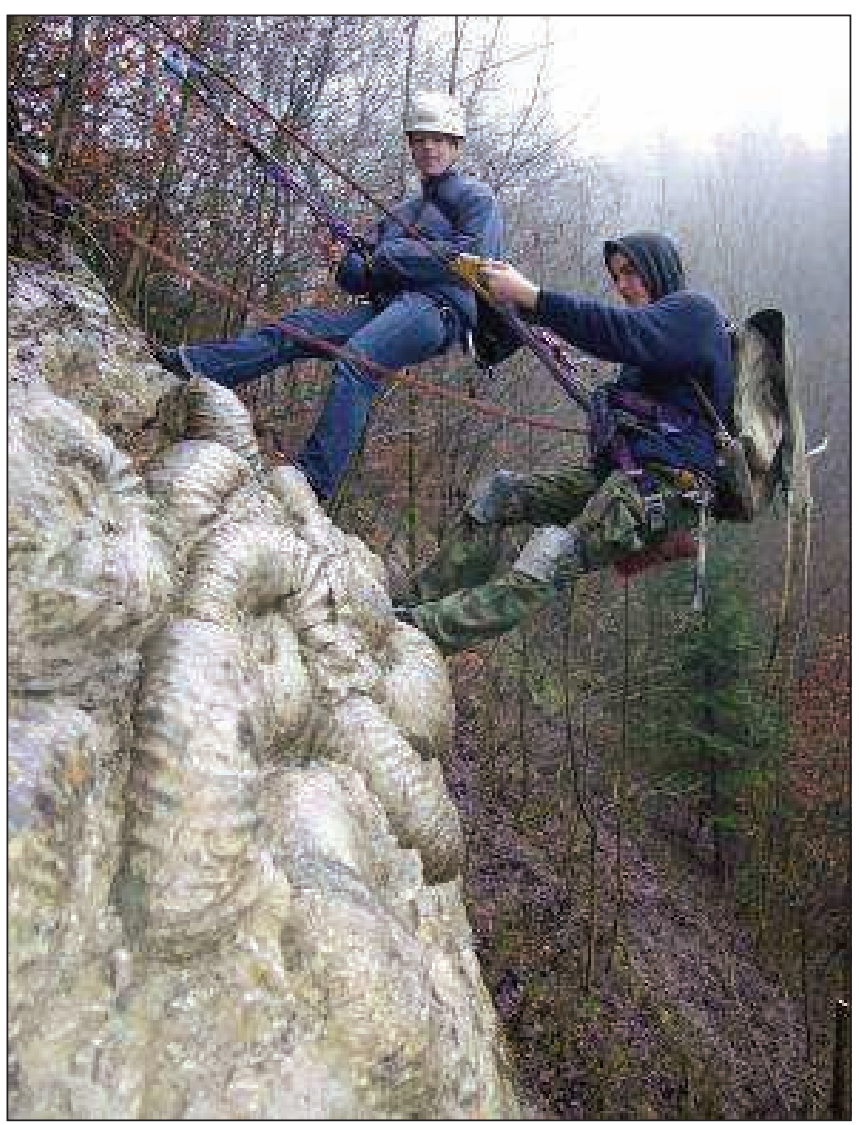

Figure 1 Worldwide largest accumulation of the huge ammonites of the endemic genus Puzosia in Late Cenomanian (Upper Cretaceous) limestones in Borgholzhausen of north-western Germany (see Fig. 2). Lateral view of the downside of the scour trough as a result of overturned strata. Visible is the lowermost layer of the prepared cephalopod steinkerns being elliptically deformed by Alpine tectonics. 
Tethyan realm into the southern boreal North Sea Basin (Diedrich, 2001b).

\section{Material and Methods}

Different sediment types of the Cenomanian/Turonian boundary, especially from the scour trough beds of Halle/Westphalia were thin sectioned for carbonate microfacies analysis (Diedrich, 2001b). A stable isotopic analysis was made in the lower part of the $\mathrm{C} / \mathrm{T}$ boundary section.

Detailed taphocoenosis of many big ammonite scour troughs was documented in complicated climbing excavation technique during 1998-2001 in two quarries at Halle/Westphalia and Borgholzhausen in the Teutoburger Wald of north-west Germany (Diedrich, 2001b). In Halle/Westphalia, the excavations during 1994-1998 on a large surface of the dimension of about three football fields (surface of $300 \times 50 \mathrm{~m}$ ) revealed 175 scour troughs and therefore a large number of shells and a lot of new taphonomic, palaeoecologic, palaeoclimatologic and finally bathymetric information. At Borgholzhausen, only four scour troughs on a small quarry wall of $10 \times 8 \mathrm{~m}$ were excavated in 2001. Additional sites were studied in the Teutoburger Wald of which the most interesting are the localities at Lengerich and a second quarry in Borgholzhausen and finally in Rheine (Fig. 2). At all localities the strata are overturned and dip $45-50^{\circ}$ to northeast. This unique situation allowed the excavation and mapping from the downside view of the scour troughs whereas the troughs build today "small hills" as a result of the overturned fossil seafloors. Also the bioturbation is perfectly preserved as a hyporelief. Because of these circumstances, bioturbation was mapped first. In the second step the giant ammonites and surrounding macrofossils larger than $0.5 \mathrm{~cm}$ were prepared in the field. They were identified and their position was exactly drawn in the field maps (Diedrich, 2001b).

About 4,000 kg material, 200 giant ammonites or at least 10,000 macrofossil remains were excavated, prepared and analysed statistically from the five scour trough levels at the base of the Puzosia
Event I of the Upper Cenomanian (Upper Cretaceous) limestones (Diedrich, 2001b). The sediment from many scour troughs was sieved additionally after processing with $\mathrm{H}_{2} \mathrm{O}_{2}$ for the search of small macroand microfossils. Especially microselachian and teleostean fish teeth, cirriped peduncles, small brachiopods, serpulids and foraminifers were isolated.

Actuopaleontological studies of recent empty nautilid shells in a current channel were made to compare shell accumulation orders in the form of chain- and fan layers such as the ones made by huge Cenomanian ammonites. During the actualistic studies at the North Sea beach of northwest Germany, the scour trough form, especially the different scour types of an u-shaped scour trough built by unidirectional currents and the elliptic scour trough type created by changing current directions were compared.

The fossil specimens of the locality Halle/Westphalia and Borgholzhausen are deposited in the Naturkundemuseum Bielefeld and ErdZeitMuseum Borgholzhasuen (both in north-west Germany).

\section{Geology, palaeoenvironment, palaeo- climate and age}

The Schwarzbunte Wechselfolge Formation (Cenomanian/ Turonian boundary), in which the giant ammonite accumulation were found at several sites in the north-western Germany, spans the uppermost Upper Cenomanian and Lower Turonian. The Schwarzbunte Wechselfolge Formation is subdivided into the Bunte Member, Karbonat Member, Schwarzschiefer Member, and the Grüngraue Mergel Member in the Teutoburger Forest region of northwestern Germany (Diedrich, 2001b-c; Fig. 2). This limestone series mainly consists of alternating tempestitic carbonate sediment types in different red, green and yellowish colours and black shale layers (Diedrich, 2001b-c). This Formation is $22 \mathrm{~m}$ in thickness at Lengerich and becomes less (about $15 \mathrm{~m}$ ) at Bielefeld (Diedrich, 2001b-c; Fig. 2). Main marker beds of the Upper Cenomanian are

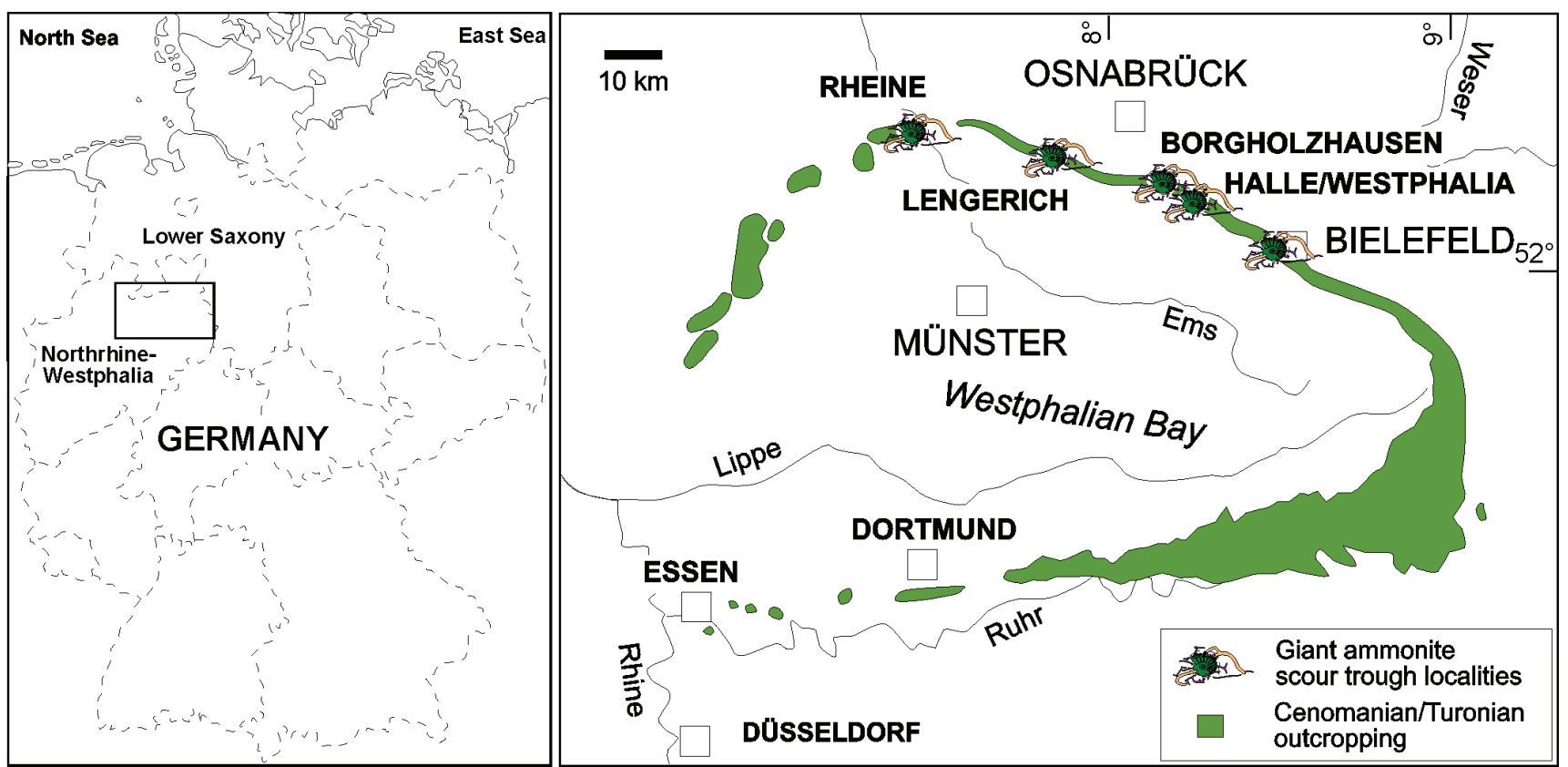

Figure 2. Late Cenomanian (Upper Cretaceous) giant ammonite Puzosia dibleyi scour trough accumulation sites in northwestern Germany. 


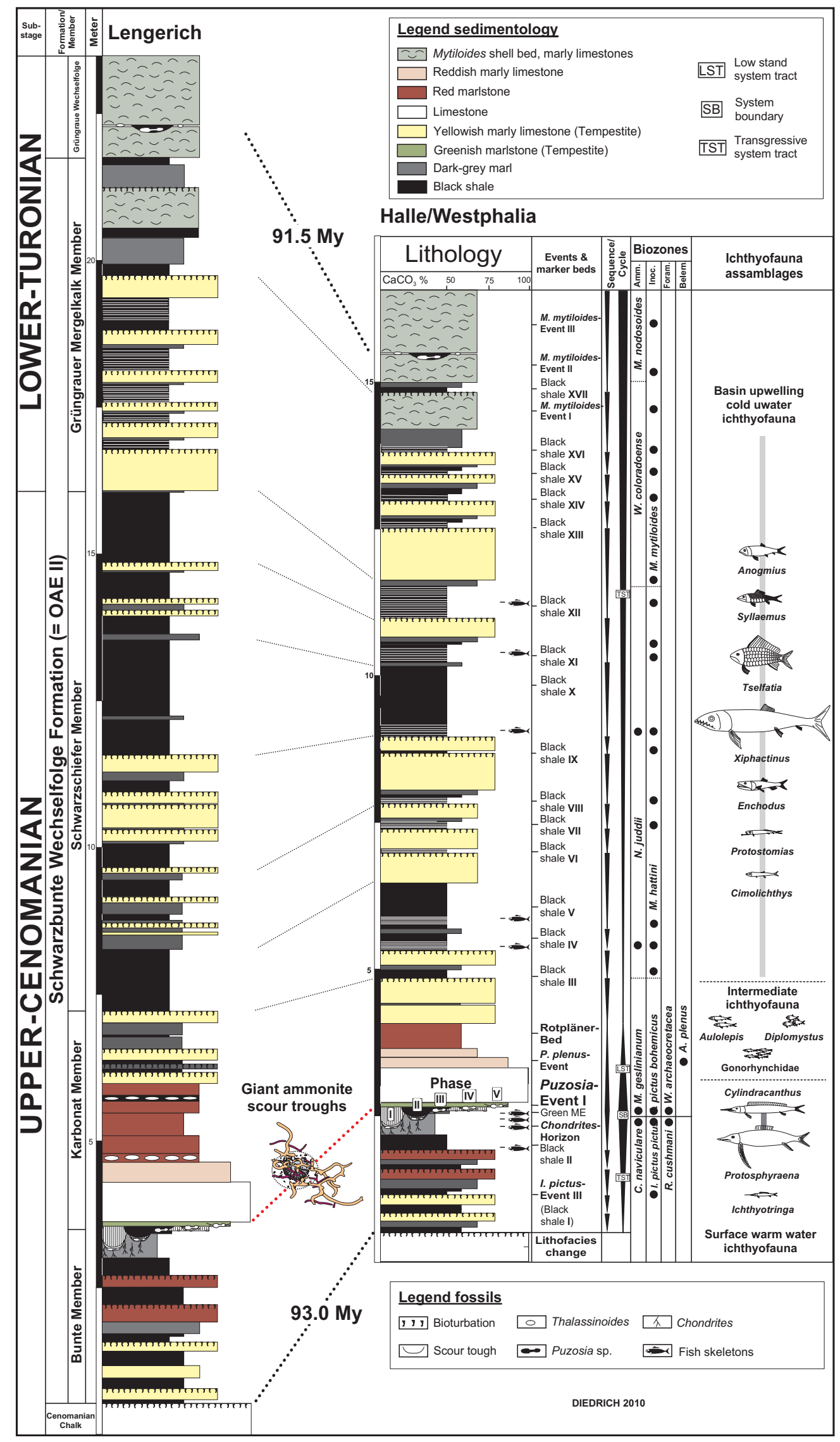

Figure 3. Stratigraphy and Late Cenomanian correlation at the giant ammonite scour trough localities Halle/Hesseltal and Lengerich, northwestern Germany (see. Fig. 2) with ichthyofaunas as bathymetric or current and water temperature indicators. the Inoceramus pictus Event III, the Chondrites Horizon, the Puzosia Event I, the Praeactinocamax plenus Event and in the Lower Turonian the Mytiloides Events I-III. Stratigraphic correlations of eleven different sites in northwestern Germany and correlations with sections in France and England show that the Puzosia event is an event in the entire southern North Sea Basin which can be found in different facies types and bathymetries as also indicated by the presence of $\delta^{13} \mathrm{C}$ and $\delta^{18} \mathrm{O}$ isotope anomalies (Diedrich, 2001b), which can even be followed to the northern Tethys (e.g. Marroc or Tunisian Basin) (Gale, 1990; Accarie et al., 1996). At the base of the PuzosiaEvent I, five high resolute stages (scouring phases I-V; Diedrich, 2001b; Fig. 2) were identified by the macrofaunal change, especially with fan layer scour troughs, in which different ecomorphotypes of the giant ammonites give precise time frames for the faunal and shell accumulation. One of the best examples is the accumulation from Borgholzhausen (Figs. 1, 4). The black shales of the Cenomanian/ Turonian boundary along the submarine swell were distributed worldwide during the transgression in upwelling influenced marine zones (Arthur, et al., 1987; Diedrich, 2001c). Clay particles, plant remains and lacertilian skeletons were transported from the eroding mainland of the Rhenish Massif into the Münster Cretaceous Basin. Here especially in the Osning Depression southern the Northwestphalian Lippe High (cf. Fig. 7) those were deposited together with many fish skeletons and inocermaid shells in rich black shales.

\section{Palaeontology}

One of the largest giant ammonite scour troughs was excavated at the site Borgholzhausen in northwestern Germany (Figs. 1-2) and this can be considered as the largest ever known Cretaceous accumulation of giant 

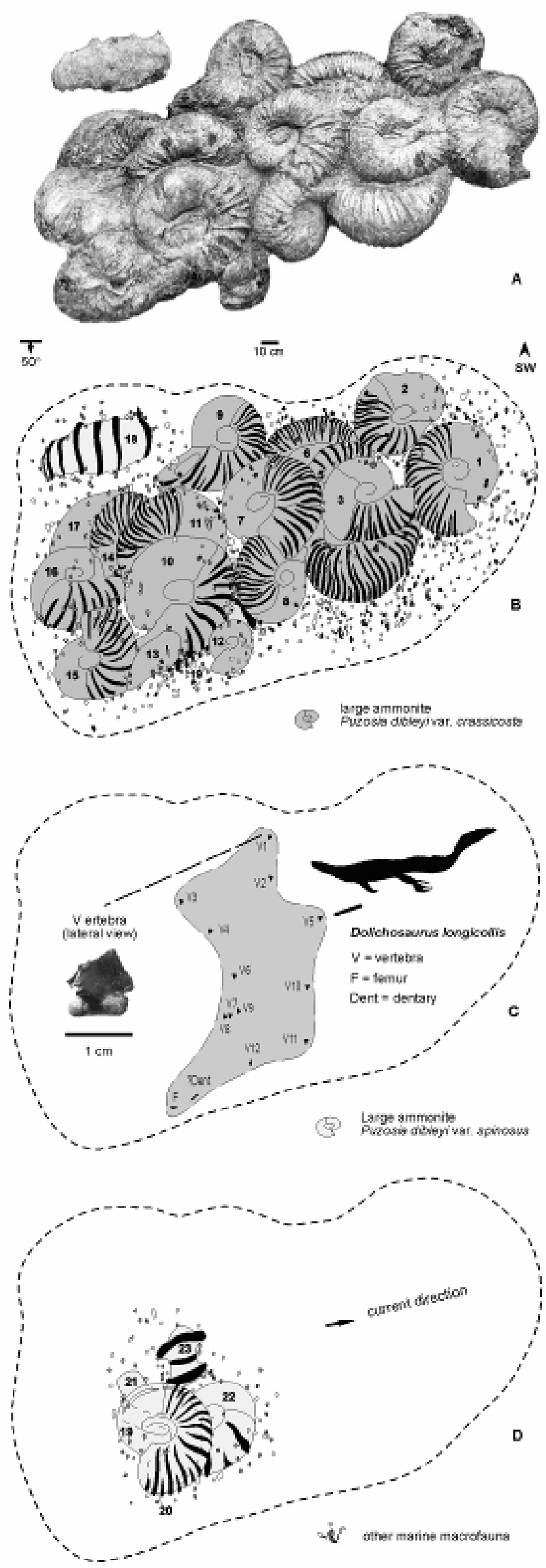

cephalopod shells in the world (Fig. 4). Eighteen cephalopods (one juvenile, 17 adult individuals) between $60-80 \mathrm{~cm}$ in diameter were found in a first lower layer (Fig. 4). Most of the ammonites have incomplete body chambers that partly indicate transport prior to accumulation and crashing of the shells against each other on the sea floor which has been documented for other ammonites and in modern nautilid experiments (Brenner, 1976; Seilacher, 1963; Futterer, 1978). In the eastern part, two more ammonites and three body chamber fragments created a fan layer scour trough type (Fig. 4). In between the ammonites hundreds of other marine invertebrate macrofossils and a few very important vertebrate fossils were found, some of them originating from the benthic islands as epizoans, others being washed into the depression. The calcitic bivalve shells and echinoderm remains are preserved, whereas the aragonitic shells of ammonites, gastropods and some bivalves are completely dissolved during late diagenesis. Therefore only steinkerns are preserved which were later deformed to elliptical shape by the alpine tectonics.

\section{Palaeobiodiversity}

The following taxa occur in the scour trough of Borgholzhausen: Reptilia: Dolichosaurus longicollis Owen; Selachii: Isurus mantelli (Agassiz), Lamna appendiculata (Agassiz), Ptychodus decurrens Agassiz, Teleostei indet.; Cephalopoda: Metoicoceras geslinianum (D‘ Orbigny), Puzosia dibleyi (Spath); Gastropoda: Bathrotomaria dixoni Cox, Turbo sublaevis (Geinitz), Perissoptera rahmani Kollmann; Lamellibranchiata: Gryphaeostrea canaliculata (Sowerby), Pycnodonte (Phygraea) vesicularis (Lamarck), Plicatula barroisi Péron, Spondylus striatus Sowerby, Inoceramus pictus bohemicus Leonhard, Echinoidea: Temnocidaris (Stereocidaris) dissimilis (Woodward); Asteroidea: Spenceraster sp.; Crustacea: Stramentum (S.) pulchellum (Sowerby); Brachiopoda: Discinisca sp., Cyclothyris compressa (Valenciennes), Orbirhynchia boussensis Owen, Monticlarella jefferiesi Owen, Ornatothyris pentagonalis Sahni; Serpulidae: Pomatoceros trachinus (Münster), Neomicrorbis crenatostriatus (Münster), Neomicrorbis voigti (Lommerzheim). This marine fauna was also documented with many more species in the scour troughs at the Halle/Hesseltal site (Diedrich, 2001b-c).

Of special interest are the bone remains of an extremely rare small marine squamate Dolichosaurus longicollis Owen (Varanoidea) found in between the giant ammonites of the scour trough in Borgholzhausen and other few remains in Halle/Westphalia (Diedrich, 1999). Most possibly only one individual carcass of Dolichosaurus was trapped in between the giant ammonite shells of the Borgholzhausen scour trough (Fig. 4). Only one vertebra of the lacertilian Dolichosaurus and one jaw fragment of the smaller squamate Coniasaurus crassidens Owen (Varanoidea) were found at the scour trough site Halle/ Westphalia in north-western Germany (Diedrich, 1997a). May be the

Figure 4 Largest accumulation of the ammonite Puzosia dibleyi in Late Cenomanian (Upper Cretaceous) strata of northwest Germany. View onto the downside of the scour trough as a result of overturned strata; all figures retrodeformed. A. Photo of the lower layer. B. Lower layer finding map showing the large ammonites and surrounding macrofauna. $C$. The remains of the marine squamate Dolichosaurus longicollis Owen. D. Location map of the upper ammonite layer and the surrounding macrofauna which is described in the text. The bottom current direction can be estimated by the accumulation order of the drifted ammonite shells. 
lizards and possibly the crustaceans as well used the body chambers for hiding. For sure such benthic islands were optimal food sources for the marine small ancestors or relatives of the mosasaurs, and also for crustaceans and other animals.

\section{Giant ammonite shell taphonomy}

Giant ammonites accumulate in repeating similar orders resulting from the amount and overlapping of the shells as chain-, fan- or fan- layer types (Fig. 7). Chain orders consist of two or three shells in a row. With more shells accumulating they built in a next stage triangular fan-like scour troughs (about 4-12 shells). If those accumulate even longer and with further ones the scour trough deepens and can catch more ammonites in a second layer (= fan layer).

The accumulation order of the ammonite shells in the huge fan layer scour trough of Borgholzhausen can be estimated by comparison to 175 scour troughs of the second large and well studied site Halle/ Westphalia, where the main taphocoenosis types are very different in
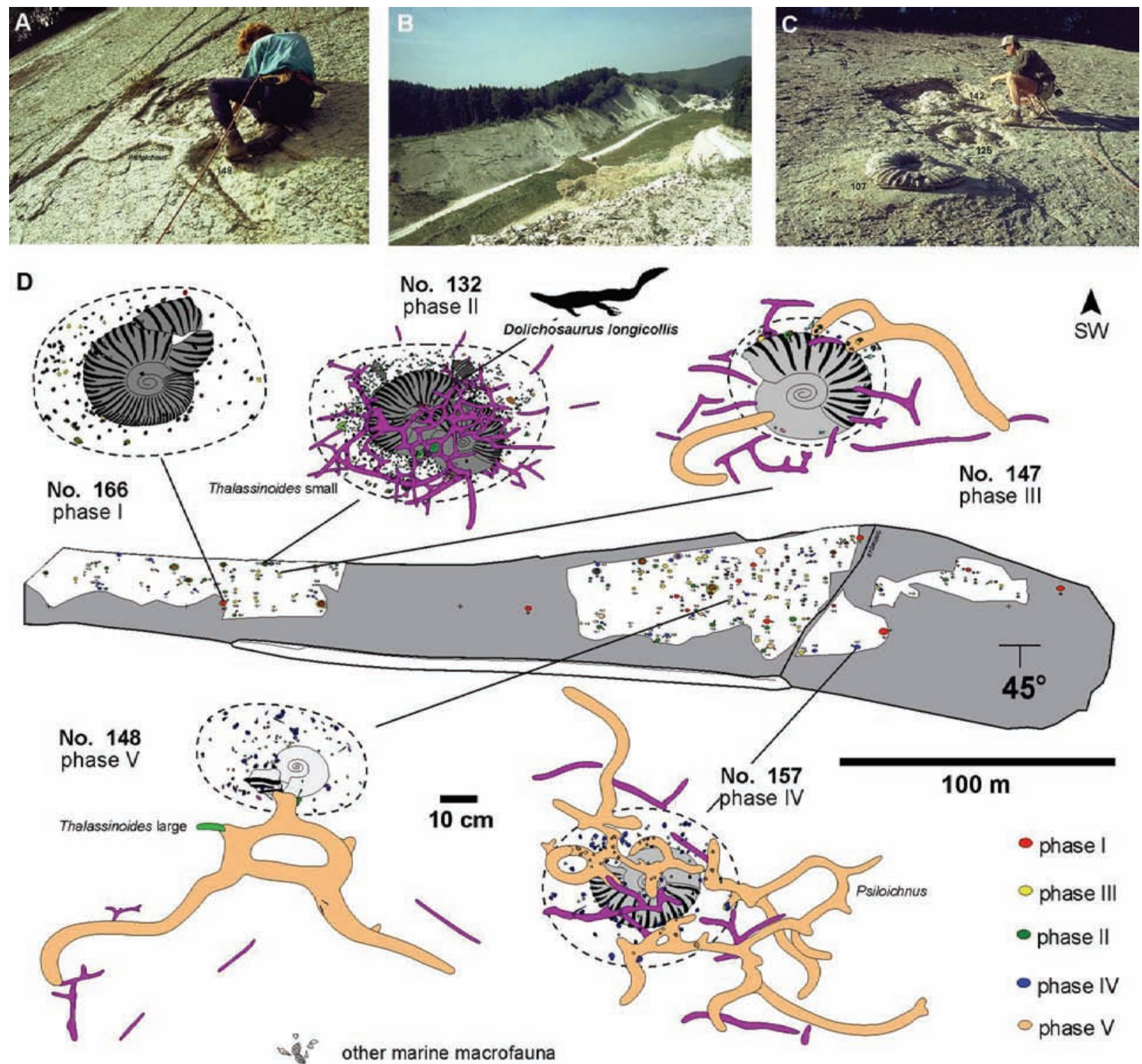

Puzosia dibleyi var. tenuicosta

Puzosia dibleyi var. crassicosta

Puzosia dibleyi var. spinosus

Figure 5. Giant ammonite scour troughs at the Late Cenomanian (Upper Cretaceous) site Halle/Westphalia, northwest Germany. A. Excavation at the scour trough no. 148 with the thick Psiloichnus burrows. B. Overview onto the large quarry wall excavation surface. C. Three giant ammonite scour troughs $(n o .107,125,142)$ with the ammonite steinkerns prepared in the wall. D. Scour troughs deformed ellipsoidal, and in down side view at the base of the Puzosia Event I. Here five examples of 175 excavated scour troughs mapped in detail on a large surface are selected representing the five different taphocoenosis types of the shallowing up phases. The bioturbation was first possible in phase II into firmgrounds in which only small Thalassinoides are present. In phase III and IV first Psiloichnus burrows are well preserved building in phase $V$ nearly the only bioturbation around giant ammonite scour troughs. The ammonite shell morphology changes in the facies areas from larger fine-ribbed (phase I-II) over coarse-ribbed (phase II-IV) to smaller spine wearing (phase V) variants of P. dibleyi (see Fig. 6). 


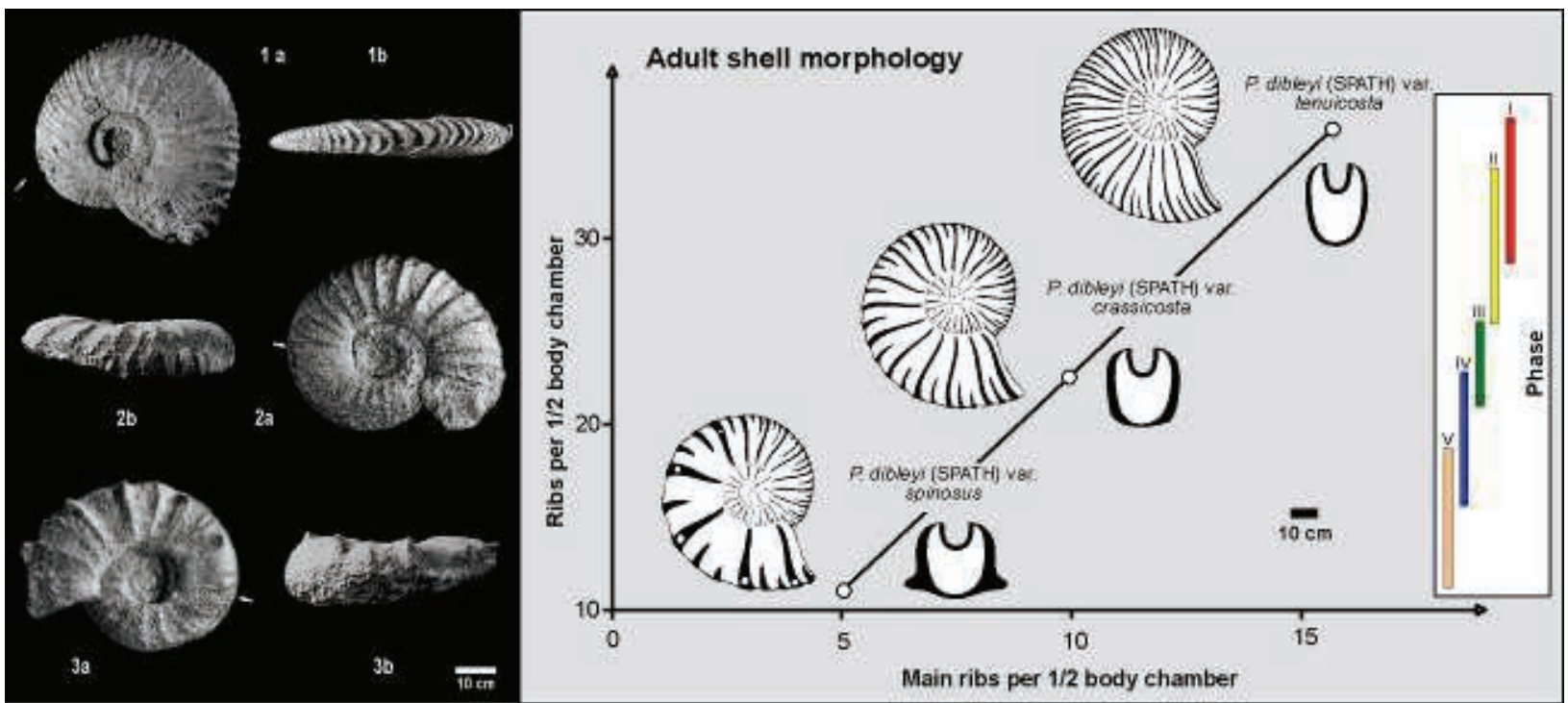

Figure 6. Facies ecomorphotypes of the giant ammonite Puzosia dibleyi, which appear in different facies types (see Fig. 7). Whereas the young individuals have similar ornamentation, only the body chamber of large individuals allows distinction between the three main forms.

five scour trough phases (Diedrich, 2001b; Fig. 5). Around the steinkerns 1-9, the typical macrofauna such as the infaunal aporrhaid gastropod Perissoptera rahmani Kollmann and the epifaunal lamellibranchiate Inoceramus pictus bohemicus Leonhard are present, representing typical main benthic faunal elements of the early scouring phases II-III (Diedrich, 2001b-c). Around the eastern part of the huge scour trough (ammonites 10-23), the macrofauna changed to an epizoan and epifauna dominated terebratulid brachiopod Ornatothyris pentagonalis (Sahni) and large oyster Pycnodonte $(P$.) vesicularis (Lamarck) faunal spectrum typical of the late scouring phases IV-V (Diedrich, 2001b; Fig. 7).

\section{Crustacean undermining bioturbation}

The different types of burrow systems of the ichnogenus Thalassinoides (Diedrich, 1997b, 2001b) were mapped at many scour troughs (Diedrich, 2001b-c; Fig. 5), with their regular network (between scour troughs) or spaghetti-like (around scour troughs) burrows. Those bioturbation types were compared with the recent burrows of the calianassid crustacean Glypterus on San Salvador, Bahamas (cf. Curran, 1997). Here different burrow types of one species are present in different environments also described for other calianassid shrimps (Griffis and Suchanek, 1991). In areas with sea grass, the burrows are irregular and short such as the ones around the fossil scour troughs. Here the crustaceans feed as drift catchers. Outside the sea grass, large network systems such as the ones in between the giant ammonite scour troughs are present indicating suspension feeding habit (Diedrich, 1997b). Additionally hook-like and up to arm thick burrows of the type Psiloichnus burrow systems produced by another large shrimp (lobster) are only present in the shallowest facies (phase IV-V, Fig. 5).

\section{Giant ammonite shell ecomorphology}

The hemibenthic large ammonites show a different morphology only in the outer body chamber whorl depending on the facies type (Fig. 6), which is quite unique for giant ammonites (Diedrich, 2000a). In the early scour trough levels of phase I-II of the deeper ramp facies, fine sculptured ecomorphotypes are present with $P$. dibleyi (Spath) var. tenuicosta. In the levels III-IV of the slope facies the body chamber of $P$. dibleyi (Spath) var. crassicosta is coarsely ribbed, and finally in the level V of the shallow water submarine swell facies very large spines up to $10 \mathrm{~cm}$ are present on $P$. dibleyi (Spath) var. spinosus (Diedrich, 2000a). The latter two types can be observed in the huge scour trough of Borgholzhausen indicating facies change (ramp to swell facies, Fig. 7) as a result mainly of tectonic uplifting of the submarine swell, but also global eustatic changes. The steinkerns 117, 19-20 belong to $P$. dibleyi var. crassicosta, and the rest to $P$. dibleyi var. spinosus. As a result of the changing macrofauna (Fig. 7) and shell morphology of the giant ammonites (Diedrich, 2000a), the accumulation order can be observed at the new huge scour trough of Borgholzhausen beginning in the scour trough phase II. The first deposited ammonite in the western part of the trough (No. 1) represents the slope ecotype $P$. dibleyi var. crassicosta and was the reason for this large accumulation. With bottom currents directed to northwest, more and more ammonite shells accumulated behind the first one. Other macrofaunal remains were partly caught in the large fossil trap over a longer period, and not by a short event, other ones are remains from animals which lived between and on those ammonite shells. A first layer of several P. dibleyi var. crassicosta shells created at first a fan scour trough. A second ammonite layer with $P$. dibleyi var. crassicosta and $P$. dibleyi var. spinosus finally built up a fan layer scour trough type, which was documented only two times in Europe (Diedrich, 2001a-b). The more fragmentary preservation of the last accumulated ammonites or body chambers of spine-bearing ecotypes indicate a more turbulent shallow marine swell-facies in the late phases IV and V, additionally shown in other chain and fan scour troughs at Halle/Westphalia (Diedrich, 2001b).

\section{Benthic palaeocommunities and alpine tectonic influence}

The marine macrofauna shows the mixing of the different taphocoenosis types in the scour trough level, the Puzosia Event I, and the accumulation of the fossils during a Milancovitch-sequence (up to 10.000 years: cf. Gale, 1990). That means, the large fan layer 

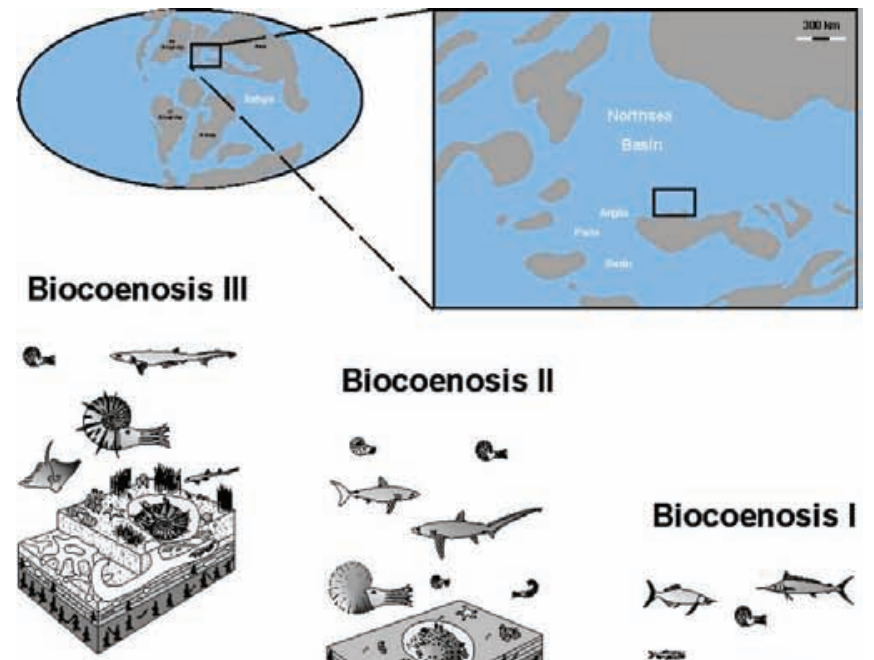

Biocoenosis II
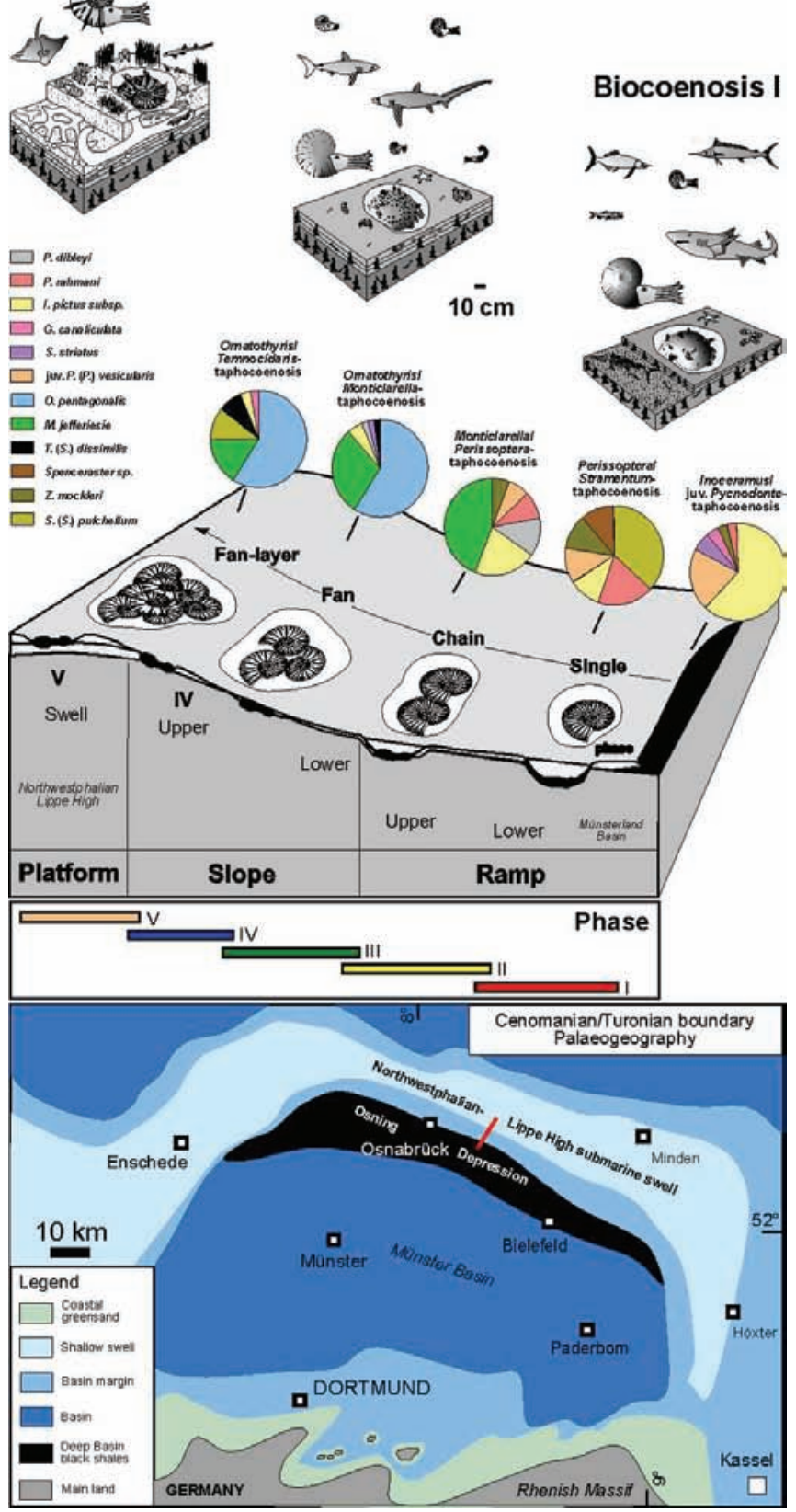

Figure 7. Taphonomy in giant ammonite shell accumulations and biocoenosis types dependent on changing bathymetry and sedimentology during the Puzosia Event I (Upper Cenomanian) in northern Germany on the margin of the Northwestphalian-Lippe High submarine swell. Remarkable are the shell morphology adaptations of the body chambers of the giant ammonites, that lived isochronously in different facies zones with one species (see Fig. 6). scour troughs, such as the one at Borgholzhausen and those of Halle/Westphalia, are not the result of storm event accumulations or short sedimentological events where shell remains were deposited in gutter or pot casts or channels such as known for shallow subtidal carbonate environments (Aigner and Futterer, 1978). In contrast, the development of a large scour trough started with a single cephalopod shell which dropped onto the plain seafloor (Fig. 7). The scouring started around the cephalopod shell whereas the degree of scouring depth depended on the degree of cementation of the carbonate sediment types. It was also the result of the changing bathymetry and facies at the margin of a submarine swell (North-Westphalian-Lippe High, Fig. 7), which coincided with the initial period of the Teutoburger Wald Mountain chain uplift.

The scour trough taphocoenosis types indicate a rapid shallowing from approximately $150 \mathrm{~m}$ to $30 \mathrm{~m}$ or even lower water depth (Fig. 7). The change in the Puzosia Event I from an Inoceramus/ juvenile Pycnodonte softground biocoenosis of the deeper marine ramp facies to a Perissoptera/juvenile Pycnodonte softground biocoenosis of the slope facies to the shallow water Ornatothyris/ Temnocidaris/Thalassinoides firm ground biocoenosis of the swell facies indicate a fast facies and bathymetric change at the southern margin of the Northwestphalian-Lippe high in the boreal southern North Sea Basin. This can only be explained by the combined effects of tectonic uplift and eustatic changes, possible results of the greenhouse world. This had a strong effect on the marine palaeocommunities which accumulated in many cases postmortally only in the scour trough taphocoenosis. In those, the ammonite shells were the only hardgrounds in soft carbonate substrates and were therefore incrusted by epizoans such as foraminifers, serpulids, oysters or cirripeds (Diedrich, 2001b).

\section{Stable isotopes, palaeooceanography and fish faunas}

The Puzosia Event I in the late Upper Cenomanian represents the sequence boundary during a short term cycle and shows a worldwide facies breaking event with stable $\delta^{13} \mathrm{C}$ - und $\delta^{18} \mathrm{O}$-isotope anomalies and a faunal cut (e.g. Ernst et al., 1984; Hilbrecht, 1986; Schlanger et al. 1987; Arthur et al. 1987; Gale, 1990; Accarie, et al. 1996; Diedrich, 2001b). After Hilbrecht \& Hoefs (1986) the ocean temperatures and evaporations and salinities are the main factors for the $\delta^{18} \mathrm{O}$ anomalies, which are also documented in the Puzosia Event I at the Halle/Westph. section (Diedrich, 2001b). Jenkyns (1980) explained the global lower oxygen presence in the ocean water during the OAE II and especially the Puzosia Event I to A. plenus Event by high zoo- and phytoplankton blooming in the surface waters. Those seem to have affected the lower water masses. With the moving "oxygen minimum zone" (= OMZ) within the water column (cf. Leary et al., 1989) first the deeper water plankton foraminifers (Rotalipoids), then medium water column calcareous (Praeglobotruncanids) and finally the surface water forms (Hedbergellids) show mass mortalities (Leary et al., 1989; Hart and Leary 1990; Corfield et al., 1990; Hilbrecht et al., 1992), which was also be proven in the Halle/Westph. section (Diedrich, 2001b). The positive movement of the $\delta^{18} \mathrm{O}$ curve, also found in the Puzosia Event I at Halle/Westph. (Diedrich, 2001b), is interpreted as a temperature change (Hilbrecht, 1986) and suggested first a world-wide cooling during the OAE II. After the results from the sections in northwestern Germany a cool temperature can be demonstrated only for 
the lower water column and its fauna and black shale deposits. This must have resulted from palaeo-oceanographic complex current changes, which also affected different faunas and deposition of different sediments in north-western Germany (cf. Fig. 2). The $\delta^{13} \mathrm{C}$ anomaly in the Puzosia Event I/A. plenus Event must have been caused by palaeocurrent water mixing of surface and bottom water currents, which also the fish fauna reflects well (Fig. 2). The "warm surface water fish fauna" occurs with the Hedbergellid-rich sediments (e.g. Green ME layer and Chondrites Horizon, Fig. 2). In the black shales with their dominant Rotalipoid planktonic foraminifers the "cold upwelling water basin fish fauna" is associated often with many inoceramids, whereas even rare deep-sea barbell-luring fishes of Protostomias support an arctic uppweling origin which influenced the North Sea Basin from the north (Figs. 2, 7). In the Pre-North Sea Basin different currents must have mixed with the Proto Golf, the West Tethys and the North Sea currents (Ernst et al., 1984), fish fauna and benthic island palaeocommunities agree with this theory.

\section{Conclusions}

With the analysis of 10,000 macrofossils including about 200 giant ammonites and many microfossils from five taphocoenosis types of Upper Cenomanian (Upper Cretaceous) giant shell accumulations at several sites in northwestern Germany, three different biocoenosis types were reconstructed in the Late Cenomanian Puzosia Event I. These were found in the southern Pre-North Sea Basin of Central Europe in carbonate ramp and swell positions. Though not representing the complete biodiversity of that period, which is found with the vertebrates and other invertebrates in the black shales, they provide the first ever detailed insight into the ecology of the palaeocommunities around unique Upper Cretaceous "benthic hardground islands". The large ammonite shells and their accumulations responded to green house world influenced warm surface and cold upwelling bottom current directions (influencing also the fish fauna) and the alpine tectonic uplifting and the resulting palaeoenvironmental change along a submarine swell, the Northwestphalian-Lippe High (today Wiehen Mountains and Teutoburger Forest Mountain chains). In front of this swell in the south, black shales were deposited in the Osning Depression north of the northern Münsterland Cretaceous Basin and preserve pelagic fish fauna (skeleton remains) of the Cenomanian/Turonian boundary age, whereas only disarticulated fish remains were preserved in the scour troughs.

\section{Acknowledgements}

I thank the land owners E. Dieckmann and W. Wesselmann for the excavation permissions. The research project about large ammonite scour troughs was supported by grants, between 1994-2001, from the Deutsche Forschungsgesellschaft (DFG Str.98/3), the Land North-Rhine Westphalia (City Halle/Westph.), the Landkreis Osnabrück, the Bezirksregierung Detmold, the Naturparkverein Nördlicher Teutoburger Wald-Wiehengebirge e.V., the Heimatverein Borgholzhausen e. V., and the Naturkundemuseum Bielefeld.

\section{References}

Accarie, H., Emmanuel, L., Robaszynski, F., Baudin, F., Amédro, F., Caron, M. and Deconinck, J.-F., 1996, La géochimie isotopique du carbone $\left(\delta^{13} \mathrm{C}\right)$ comme outil stratigraphique. Application à la limite Cénomanien/ Turonien en Tunisie centrale. Comptes Rendues de l' Academie de Science Paris, v. 322 (2a), pp. 579-586.

Aigner, T. and Futterer, E., 1978, Fossil-Lagerstätten Nr.44: Kolk-Töpfe und -Rinnen (pot and gutter casts) im Muschelkalk - Anzeiger für Wattenmeer? Neues Jahrbuch für Geologie und Paläontologie Abhandlungen, v. 156, pp. 285-304

Arthur, M.A. Schlanger, S.O. and Jenkyns, H.C., 1987, The CenomanianTuronian oceanic anoxic event, II. Palaeoceanographic controls on organic-matter production and preservation. Geological Society Special Publications, v. 26, pp. 401-420.

Brenner, K., 1976, Ammoniten-Gehäuse als Anzeiger von Paläo-Strömungen. Neues Jahrbuch für Geologie und Paläontologie Abhandlungen, v. 151, pp. 101-118.

Bromley, R.G., 1990, Trace Fossils (Biology and Taphonomy). Special Topics in Palaeontology, v. 3, pp. 1-280.

Corfield, R.M., Hall, M.A. and Brasier, M.D., 1990, Stable isotope evidence for foraminiferal habitats during the development of the Cenomanian/ Turonian oceanic anoxic event. Geology, v. 18, pp. 175-178.

Curran, H.A., 1997, Pleistocene, Holocene, and Modern Environments. In: Curran, H.A. (ed.), Guide to Bahamian Ichnology. Bahamian field station, San Salvador, pp. 33-37.

Diedrich, C., 1997a, Ein Dentale von Coniosaurus crassidens Owen (Varanoidea) aus dem Ober-Cenoman von Halle/Westf. (NWDeutschland). Geologie und Paläonologie in Westfalen, v. 47, pp. 43-51.

Diedrich, C., 1997b, Thalassinoide Bioturbation um Großammoniten-Kolke und ein Treibholz aus dem Ober-Cenoman von Halle/Westf. (Teutoburger Wald, NW-Deutschland). Terra Nostra, v. 97(7), 43.

Diedrich, C., 1999, Ein erster Nachweis von Dolichosaurus longicollis Owen (Varanoidea) aus dem Ober-Cenoman von Halle/Westf. (NWDeutschland). Neues Jahrbuch für Geologie und Paläontologie Monatshefte, v. 6, pp. 372-384.

Diedrich, C., 2000a, Faziesabhängige Schalenmorphologie des Großammoniten Puzosia dibleyi (Spath 1922) aus dem Puzosia-Event I (Ober-Cenoman) von Europa. Senckenbergiana lethaea, v. 80(2), pp. 463483.

Diedrich, C., 2000b, Relationships between ice volume variation, 13C/180 stable isotope anomalies, and faunal changes in eustatic controlled Upper Cenomanian carbonates. In: Oschmann, W., Steininger, F.F. and Fürsich, F.T. (eds.), Biomarkers and Stable Isotopes in Palaeontology. European Palaeontological Association Workshop, pp. 29-31.

Diedrich, C., 2001a, Der Großammoniten-Kolk im Naturkundemuseum Bielefeld. Berichte des Naturwisenschaftlichen. Vereins von Bielefeld und Umgebung e. V., v. 41, pp. 45-67.

Diedrich, C. 2001b, Die Großammoniten-Kolktaphozönosen des PuzosiaEvent I (Ober-Cenoman) von Halle/Westf. (NW-Deutschland). Münstersche Forschungen zur Geologie und Paläontologie, v. 90, pp. 1208.

Diedrich, C., 2001c, Großammoniten-Kolke, Bioturbation und Fische im Cenoman/Turon-Grenzbereich von NW Deutschland. Exkursion A 1. Terra Nostra, v. 01/8, pp. 1-24.

Diedrich, C., 2001d, Large ammonite scour troughs, bioturbation and fish in the Cenomanian/Turonian boundary of northwest Germany - a new view into the palaeoecology by macrofossils and sequence stratigraphy. Bulletin de la Société d'Etude des Sciences Naturelles d'Elbeuf, v. 2001, pp. 1922, pp. 32-35.

Ernst, G., Wood, C.J. and Hilbrecht, H., 1984, The Cenomanian-Turonian boundary problem in NW-Germany with comments on the north-south correlation to the Regensburg Area. Bulletin of the Geological Society of Denmark, v. 33, pp. 103-113.

Futterer, E., 1978, Studien über die Einregelung, Anlagerung und Einbettung 
biogener Hartteile im Strömungskanal. Neues Jahrbuch für Geologie und Paläontologie Abhandlungen, v. 156, pp. 87-131.

Gale, A.S., 1990, A Milankovitch scale for Cenomanian time," Terra Nova, v. 1 , pp. 420-425.

Griffis, R.B. and Suchanek, T.H., 1991, A model of burrow architecture and trophic modes in thallassinidean shrimp (Decapoda: Thalassinidea). Marine Ecology Progressive Series, v. 79, pp. 171-183.

Hart, M.B. and Leary, P.N.,1990, Periodic bioevents in the evolution of the planctonic Foraminifera. Lecture Notes in Earth Sciences, v. 30, pp. 325-331.

Hilbrecht, H., 1986, On the correllation of the Upper Cenomanian and Lower Turonian of England and Germany (Boreal and Tethys). Newsletter in Stratigraphy, v. 15 (3), pp. 115-138.

Hilbrecht, H. and Hoefs, J., 1986, Geochemical and palaeontological studies of the $\delta^{13} \mathrm{C}$-anomaly in boreal and North Tethyan Cenomanian-Turonian sediments in Germany and adjacent areas. Palaeogeography, Palaeoclimatology, Palaeoecology, v. 53, pp. 169-189.

Hilbrecht, H., Hubberten, H.W. and Oberhänsli, H., 1992, Biogeography of planktonic foraminifera and regional carbon isotope variations: productivity and water masses in late Cretaceous Europe. Palaeogeography, Palaeoclimatology, Palaeoecology, v. 92, pp. 407-421.

Jenkyns, H.C., 1980, Cretaceous anoxic events: from continents to oceans. Journal of the Geological Society London, v. 137 (2), pp. 171-188.

Leary, P.N., Carson, G.A., Cooper, M.K.E., Hart, M.B., Horne, D., Jarvis, I., Rosenfeld, A. and Tocher, B.A., 1989, The biotic response to the late Cenomanian oceanic anoxic event; integrated evidence from Dover, SEEngland. Journal of the Geological Society London, v. 146 (1), pp. 311317.

Schlanger, S.O. Arthur, M.A. Jenkyns, H.C. and Scholle, P.A., 1987, The Cenomanian-Turonian Oceanic Anoxic Event I. Stratigraphy and distribution of organic carbon-rich beds and the marine $\mathrm{d}^{13} \mathrm{C}$ excursion. Geological Society Special Publications, v. 26, pp. 371-399.

Seilacher, A., 1963, Umlagerung und Rolltransport von CephalopodenGehäusen. Neues Jahrbuch für Geologie und Paläontologie Monatshefte, v. 11, pp. 593-615.

Seilacher, A., 1982, Ammonite shells as habitats in the Posidonia Shales of Holzmaden - floats or benthic islands? Neues Jahrbuch für Geologie und Paläontologie Monatshefte, v. pp. 98-114.

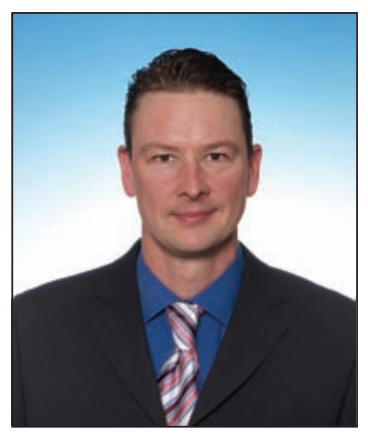

Cajus G. Diedrich is leading as a carbonate sedimentologist, palaeoecologist and prehistorian (Dr. nat. sci. in Geology/Palaeontology) the PaleoLogic Institute in Germany which is involved in Permian to Quaternary fossil excavations and research, but also in UNESCOGeopark and WORLD-Heritage fossil site developments and popular presentations in museums. His scientific broad work focuses recently on European Middle Triassic tracks/reptiles and Late Quaternary cave fauna and carnivore mammal research. 